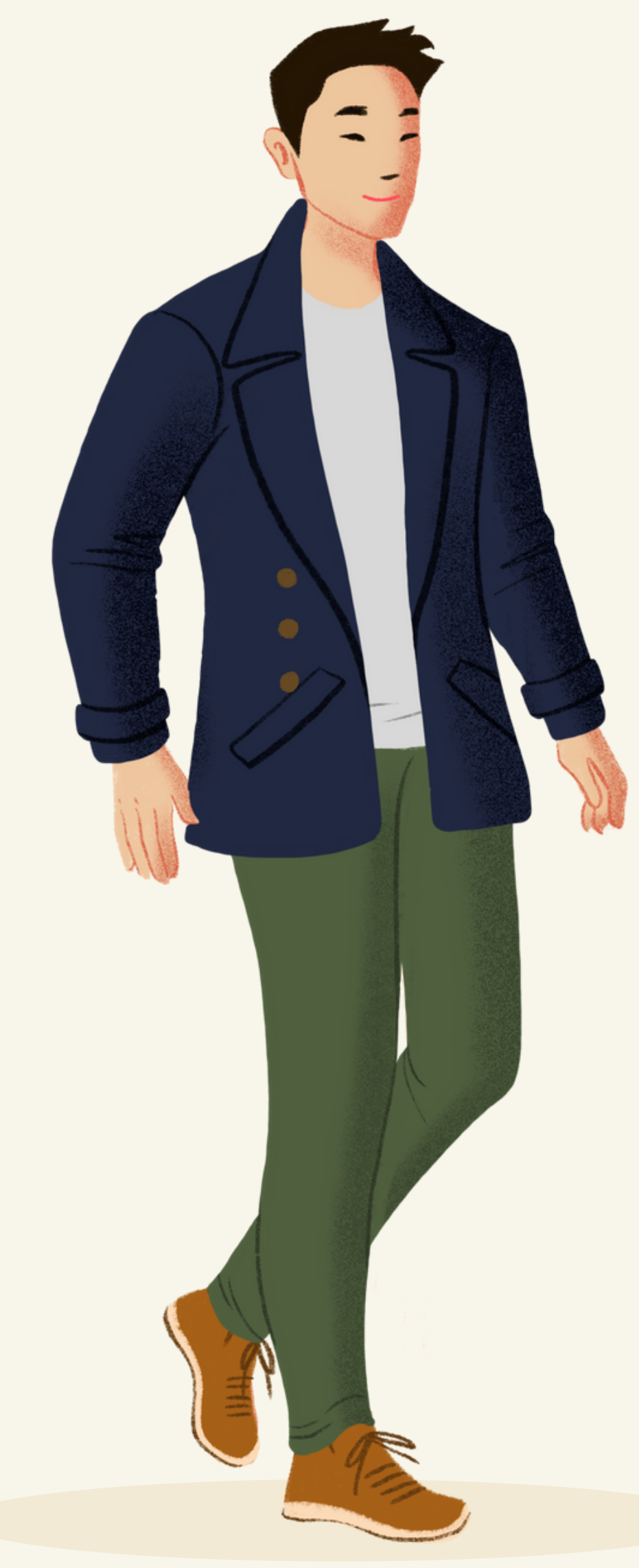

VI Congreso Internacional de Género y

Comunicación - Febrero 2021

\title{
Evaluación de la
} interseccionalidad

como herramienta de inclusión pedagógica

Alejandro de los Santos, Lourdes Aranda

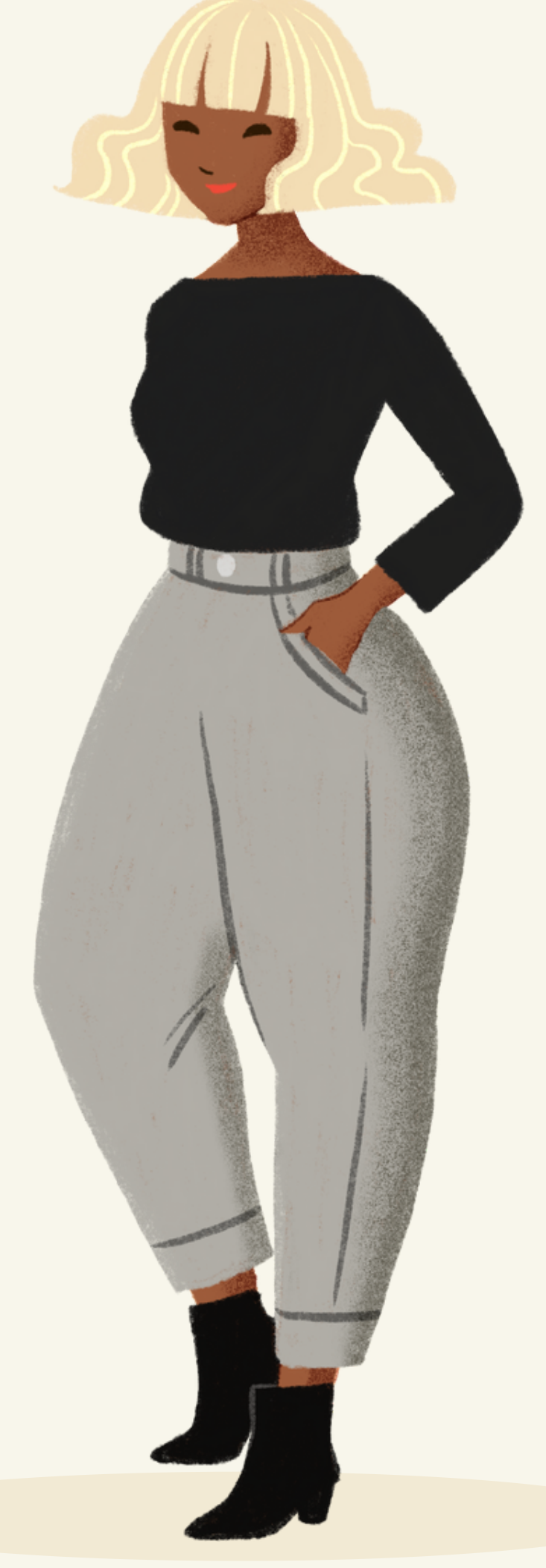




\section{Cruz Roja}

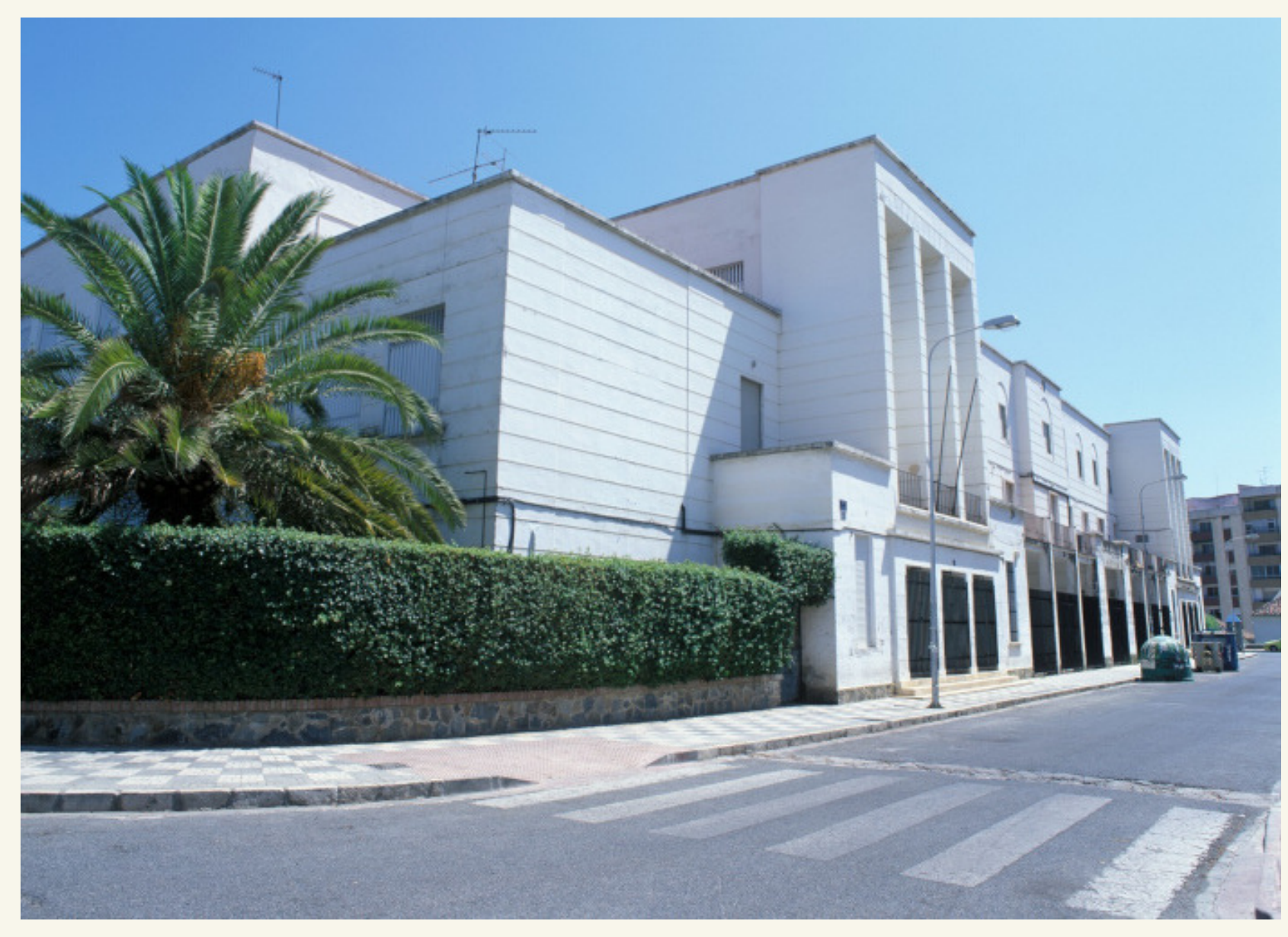

\section{Introducción}

- Sociedad multicultural y diversa afectada por cambios

- Carencia de ética y valores democráticos

- Formación del colectivo inmigrante de Cruz Roja Española (CRE) en Málaga durante su aprendizaje del castellano

- Sensibilización de la realidad y fomento de su inclusión

- Durante el confinamiento por la COVID19 


\section{Marco teórico: Interseccionalidad}

La interseccionalidad nos recuerda la importancia de las coaliciones y los aliados; nos recuerda ser humildes y buscar a quien falta en la habitación. Sobre todo, sin embargo, la interseccionalidad nos recuerda que nuestra liberación sólo se realiza cuando todos los seres son libres (Harris y Leonardo, 2018, p. 20).

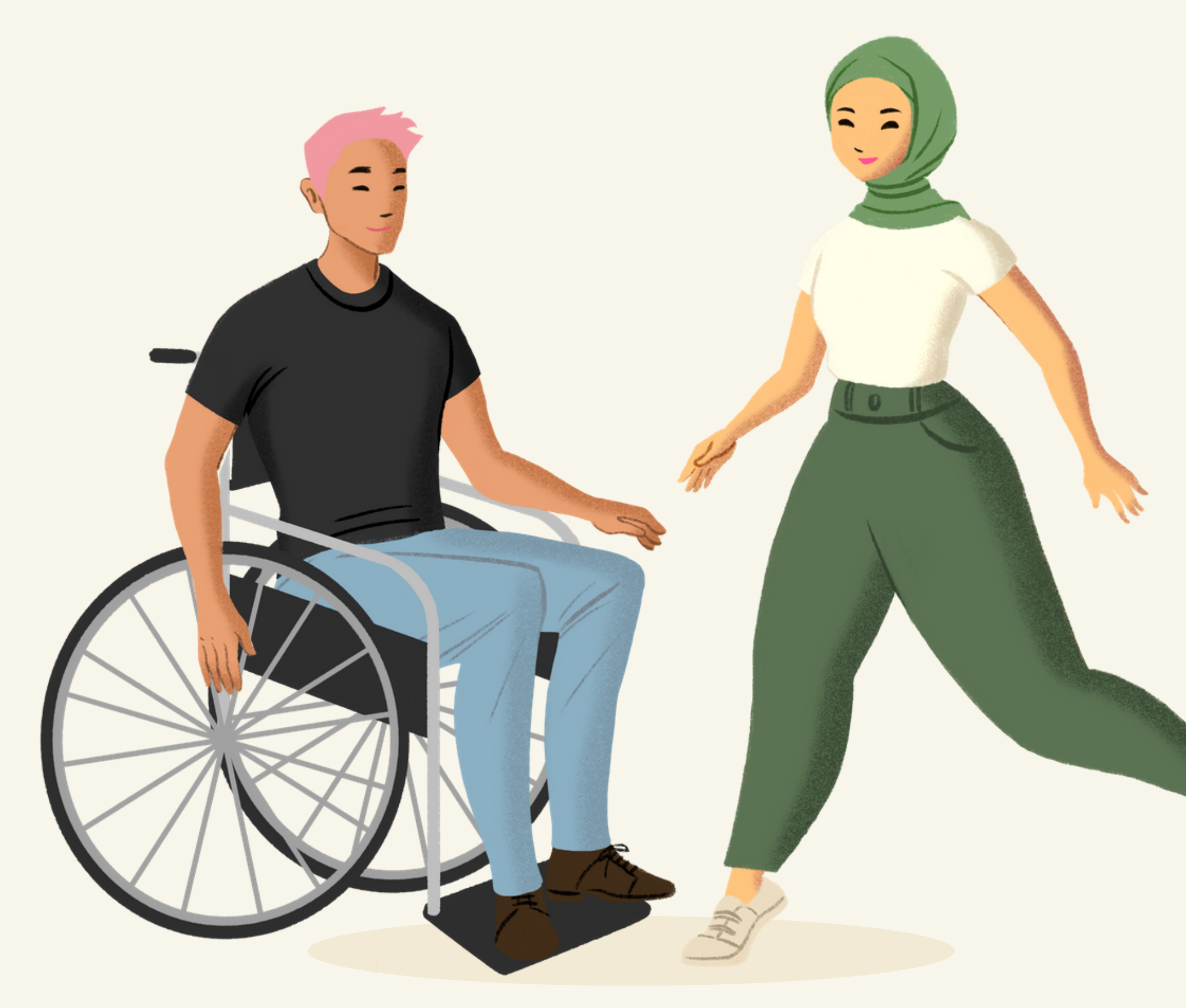




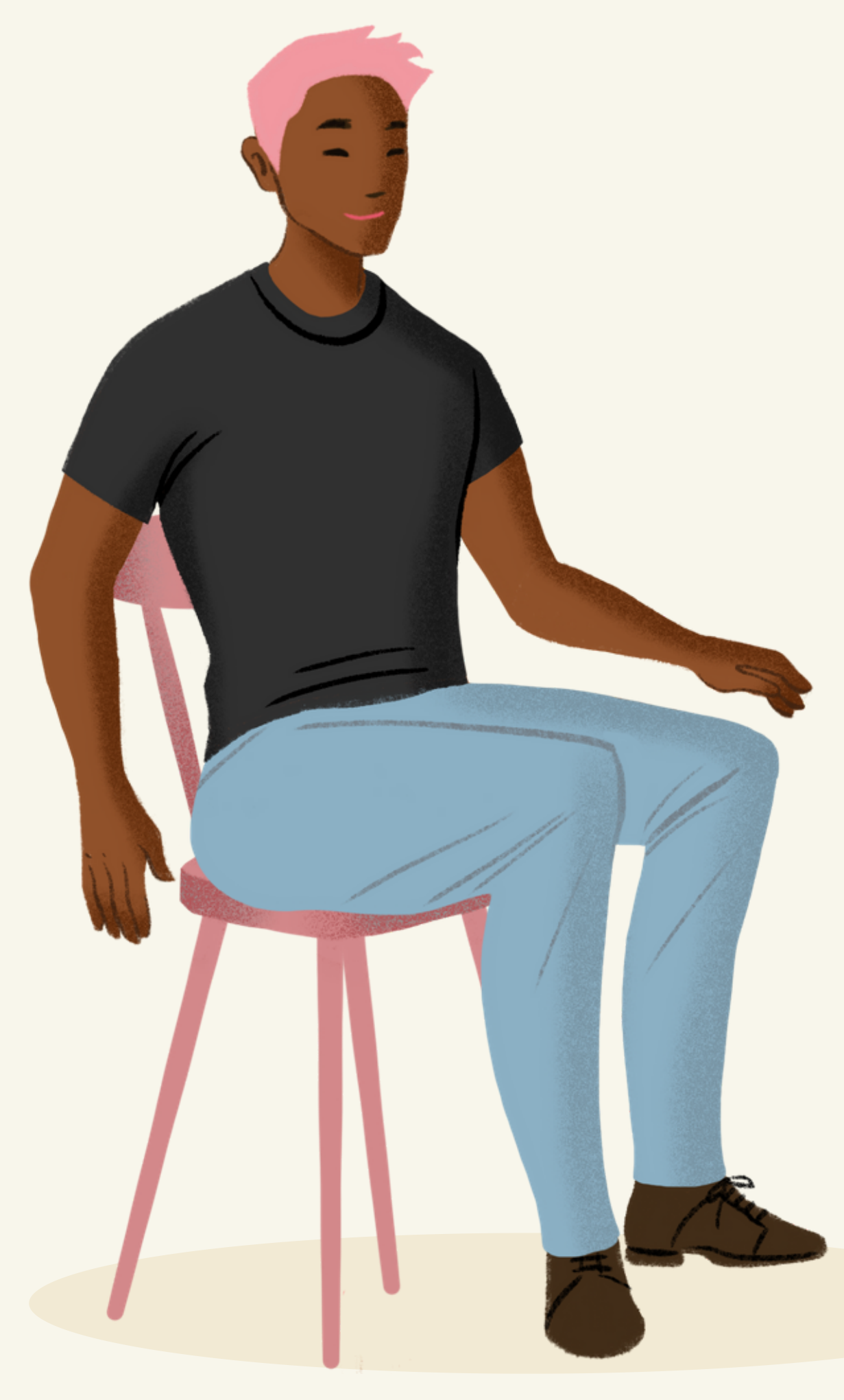

impacto social y educativo

- Concepto que es incluyente además de favorecer el desarrollo de la subjetividad e identidad personal

- Educación en valores que genere espacios de comunidad y ciudadanía

- Dentro del currículum del aprendizaje del idioma es sencillo mostrar la complejidad cultural 


\section{Objetivos}

\section{GENERAL}

- Formar desde la justicia social como enlace hacia la apreciación de la diversidad humana, desde la transversalidad del aprendizaje del idioma

\section{ESPECÍFICOS}

- Relaciones interculturales

- Distinción entre sexo y género

- Diversidad familiar y colectivo LGBT

- Diferencias humanas como riqueza 
- Prestadoras del servicio de aprendizaje del castellano dentro de la institución de CRE en Málaga

- Niveles A1 y A2 dentro del marco de referencia europeo

- 3 participantes de nacionalidades: senegalesa, ucraniana y georgiana

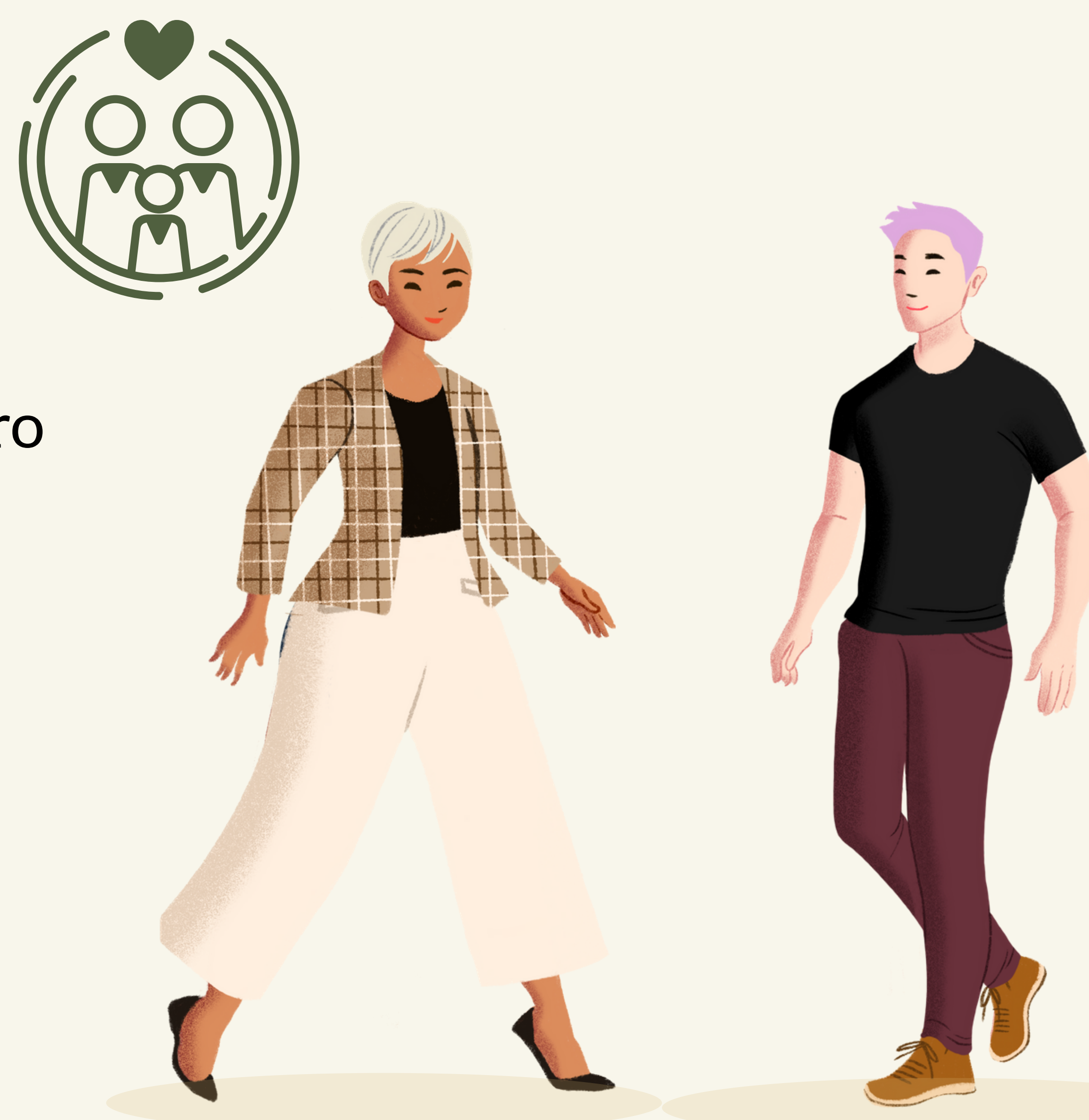




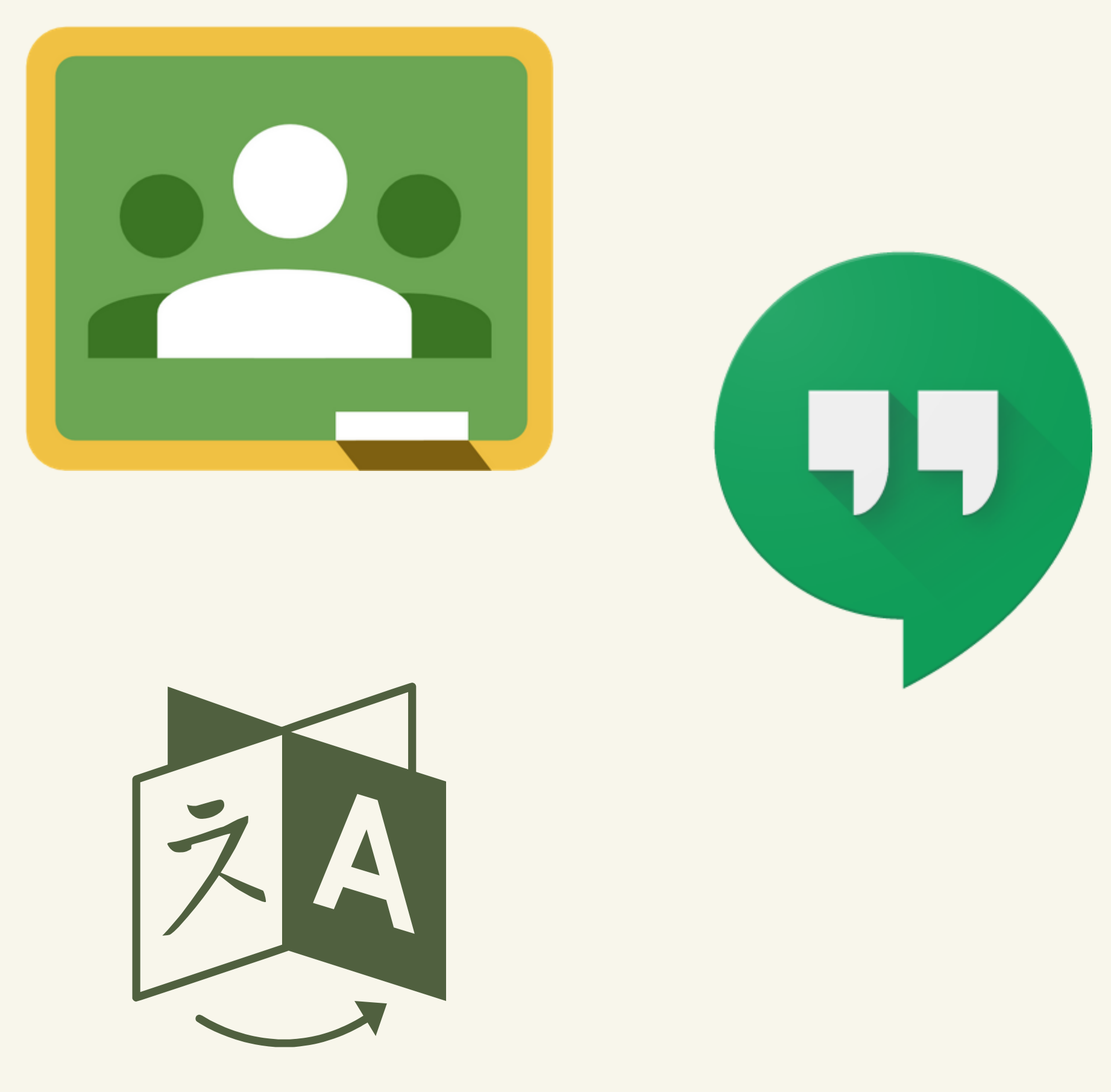

\section{Metodología}

- Uso de la plataforma de Google Classroom: aprendizaje colaborativo

- De forma ocasional Hangouts: seguimiento en su manejo con las nuevas tecnologías y conversación para su aprendizaje del idioma 


\section{Resultados}

- Elaboración de cuestionario mixto para la evaluación final

- Limitaciones a causa del estado de alarma

- La diversidad familiar no estuvo bien contemplada

- Controversia con el término "feminismo"

- Complejidad en algunas temáticas abordadas por la barrera idiomática

- Usabilidad y temporalidad del programa
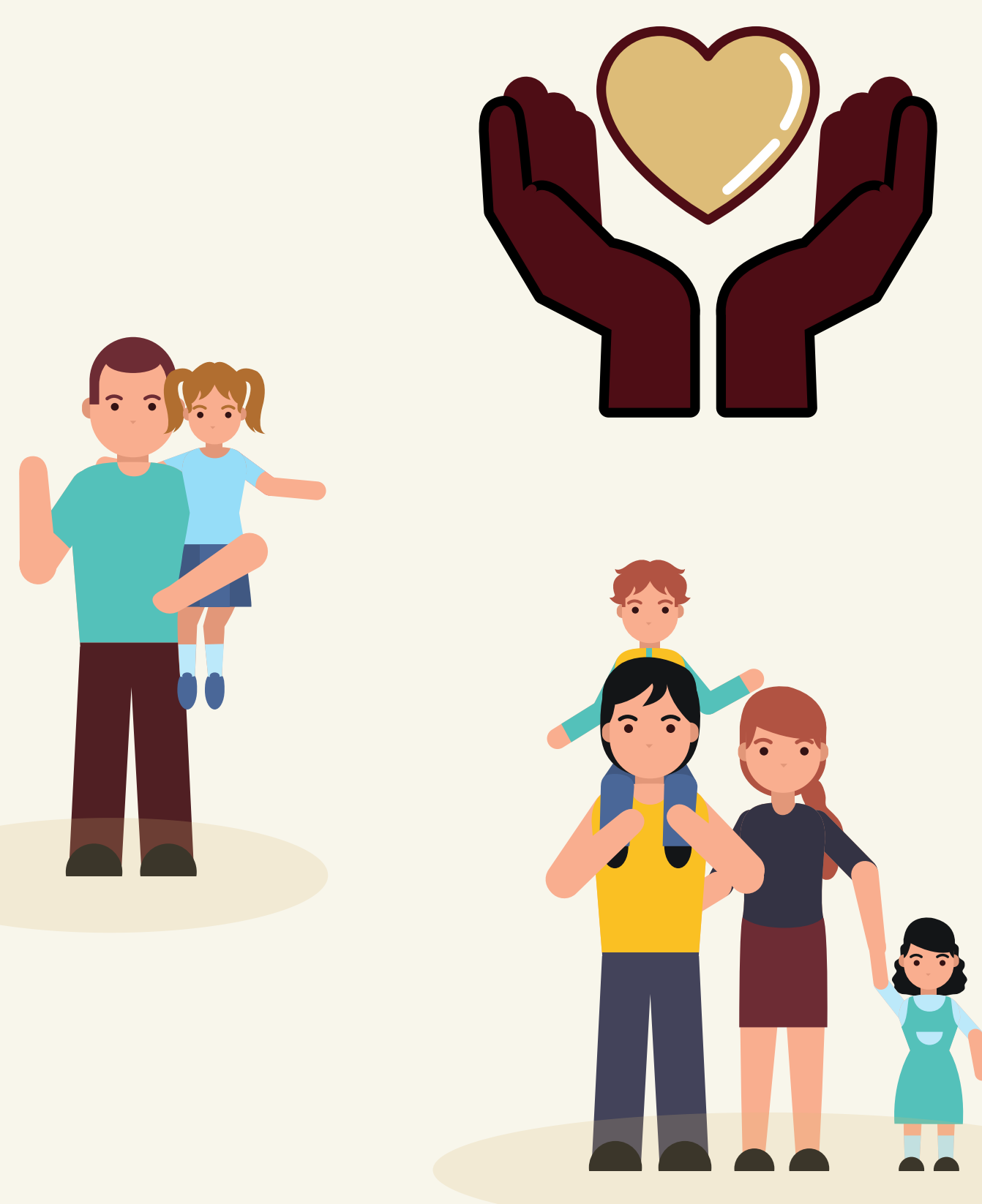


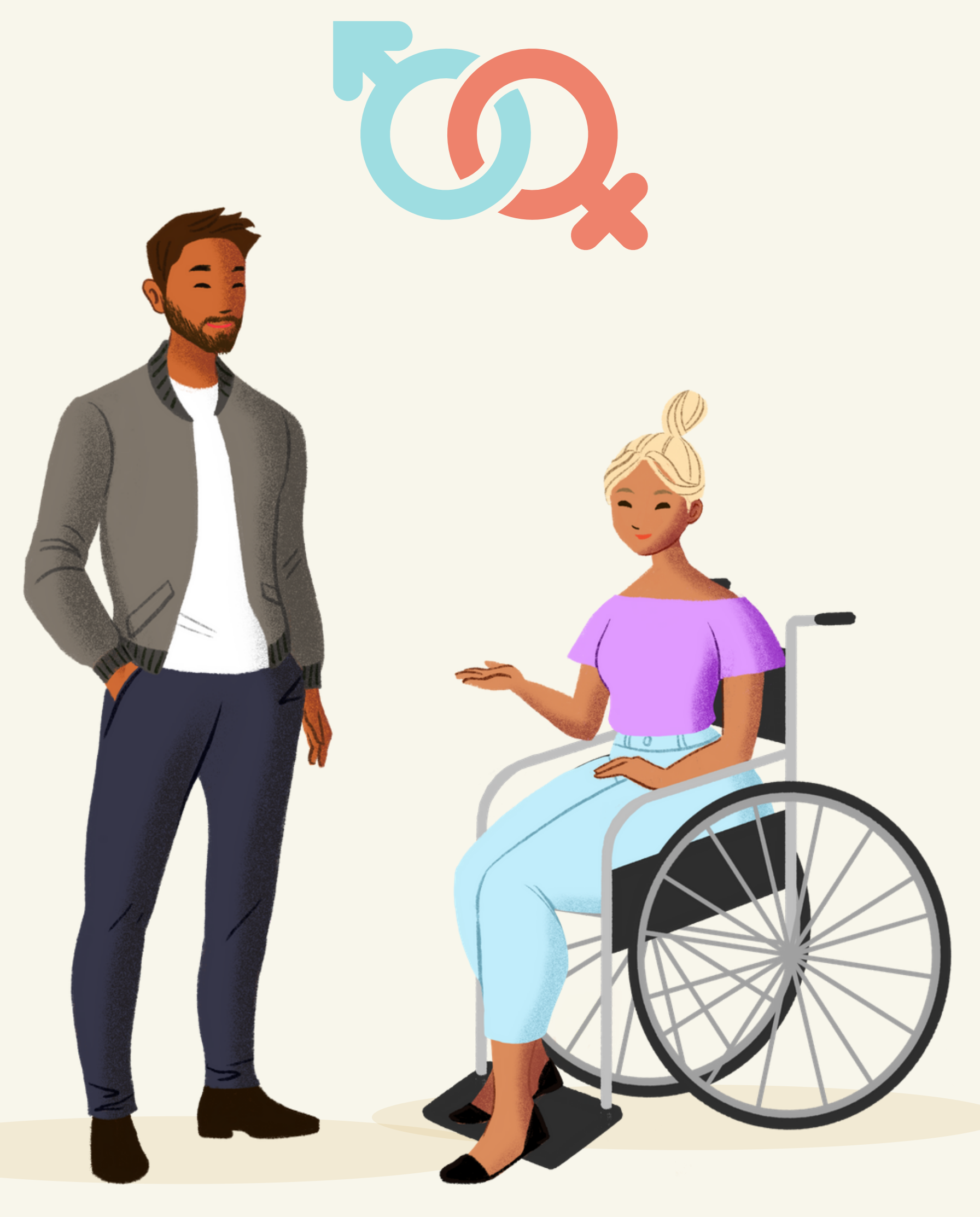

\section{Discusión}

- La aceptación en la diversidad afectivo-sexual en los modelos familiares puede deberse al origen y trasfondo sociocultural

- Carencia de metodologías activas ha dificultado la transmisión e interacción

- Escasez de espacios y recursos 
- Marcado por las consecuencias del confinamiento establecido a causa de la pandemia del virus COVID-19

- Resultados con carencias pero aún así positivos y con aprendizaje relevante

- La interseccionalidad no sólo pretende destruir las etiquetas, sino también los prejuicios ligados a ellas

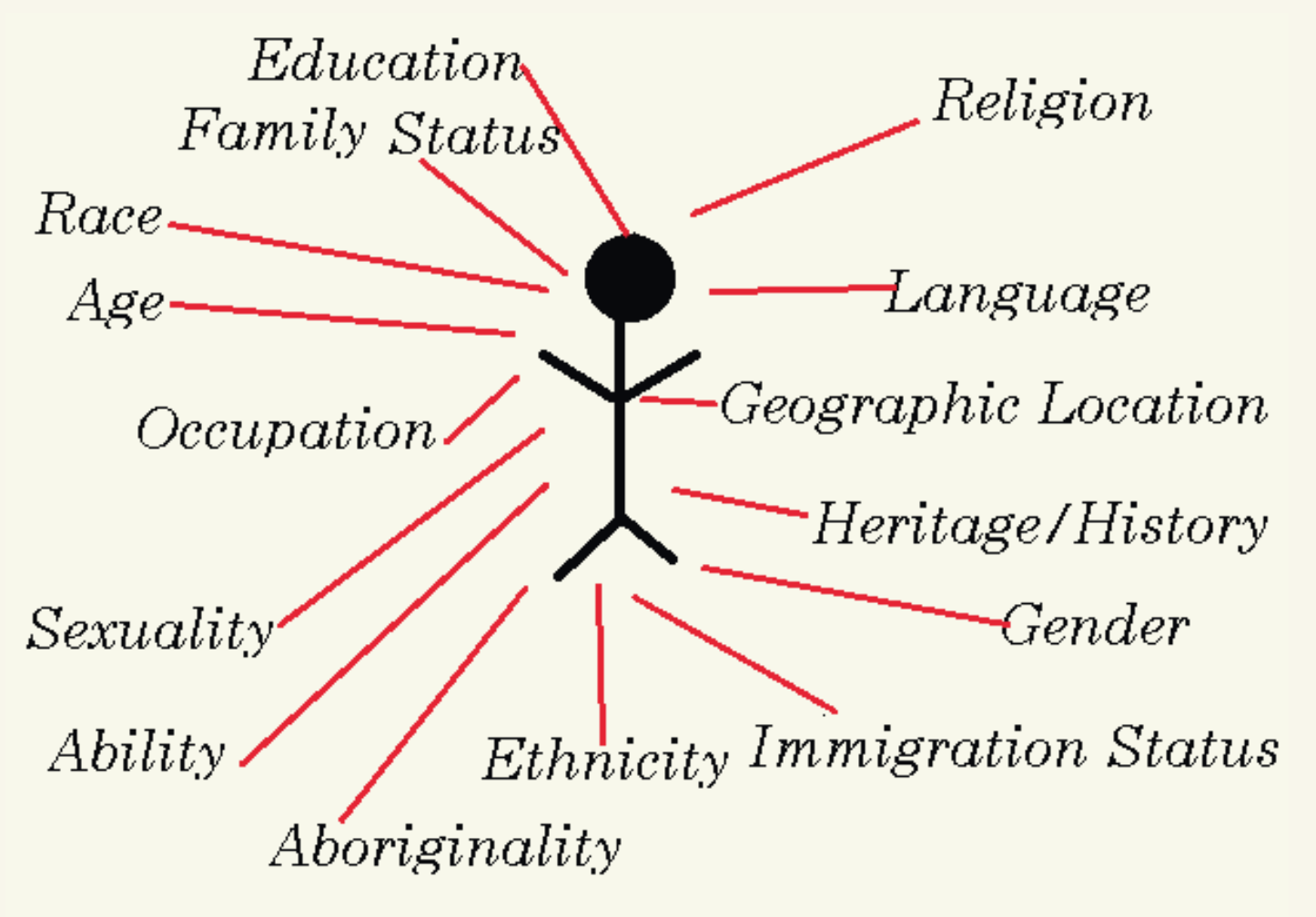




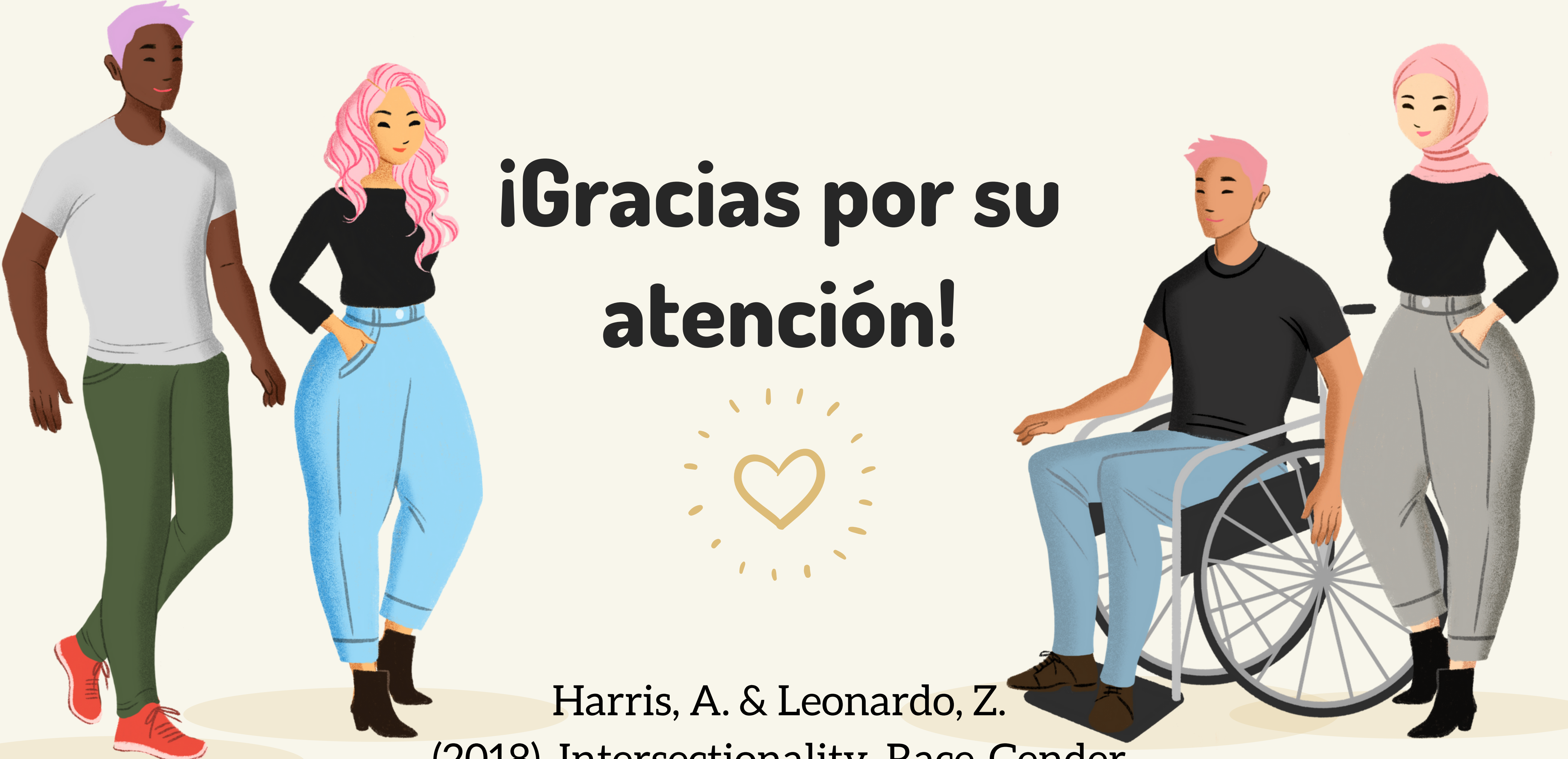
(2018). Intersectionality, Race-Gender Subordination, and Education. Review of Research in Education, (42), 1-27. 